\title{
ESCALATING ENERGY BUDGETS AND OLIGOTROPHIC REFUGIA: WINNERS AND DROP-OUTS IN THE RED QUEEN'S RACE.
}

THAYER, Charles W., Dept. of Geology, University of Pennsylvania, Philadelphia, PA 19104

Preliminary evidence supports a series of predictions and speculations that derive from the hypothesis of evolutionary escalation (Red Queen). If biotic interactions have intensified over geologic time, then:

(1) Energy budgets of individuals have increased. This involves both sides of the equation Consumption $=$ Growth + Reproduction + Respiration (includes locomotion \& feeding) + Feces + Excreta. Thus living representatives of formerly successful taxa have lower energy budgets than ecologically similar taxa that were successful later, e.g., reptiles vs. mammals, Sphenodon vs. other reptiles, brachiopods vs. bivalves, Nautilus vs. coeleoids, gymnosperms vs. angiosperms.

(2) The price of success (cals. per reproducing offspring) has increased. Thus Red Queen evolution leads to energetic inefficiency.

(3) Energetic escalation is fueled by increasing plant biomass and turnover, especially on land (angiosperms, including $\mathrm{N}$-fixers such as legumes). The enlarged trophic base pemits diversification without reduction of niche size. Evolution of marine benthos (our primary record of evolution) may be fueled directly by fixed $\mathrm{C}$ or indirectly by fixed $\mathrm{N}$ (shelf waters are normally $\mathrm{N}$-limited), both increasingly supplied from land as a result of steady state mortality (deciduousness, self-thinning, short life-cycles) or disturbance mortality (fire, wind) of bigger standing crops. The Mesozoic origin of new phytoplankton such as diatoms may be a consequence of terrestrial angiosperms. In turn, diatoms produce lipid, a more energy-dense food than the carbohydrate produced by other phytoplankton. Increased skeletonization of Mesozoic phytoplankton may have diluted the food of Paleozoic-style suspension-feeders, especially brachiopods. Brachiopods have blind guts, which they readily stuff with non-nutritive particles and tight (efficient) energy budgets that might not sustain increased feeding costs.

4) Archaic organisms survive in oligotrophic refugia that exclude more recent, high-energy enemies. Marine animals move to deeper water (explaining offshore migration over the Phanerozoic, e.g., Latimeria, Nautilus, Zoophycos.). Other refugia are high latitudes, caves, or dark fiords. Living articulate brachiopods flourish in all of these except the fluvial-influenced Arctic Ocean. Refugia for archaic flora restrict light, water, or $\mathrm{N}$ (high latitudes and elevations, forest floor, poor soil).

5) Survival in oligotrophic refugia selects for lower energy budgets, including reduction of respiring tissue, so Cope's Rule is reversed (thecideid brachiopods, lycopods, sphenopsids). 